\title{
PERCEPTIVE-MOTOR SKILLS IN CHILDREN WITH DEVELOPMENTAL
} DISABILITIES

\section{PERCEPTIVNO-MOTORIČKE SPOSOBNOSTI KOD DJECE SA TEŠKOĆAMA U RAZVOJU}

\author{
Adelisa Salkić ${ }^{1}$, Milena Nikolić ${ }^{2}$ \\ ${ }^{1}$ Center for Early Intervention "Little World", Bistarac Donji bb, 75300 Lukavac, Bosnia and \\ Herzegovina \\ ${ }^{2}$ Faculty of Education and Rehabilitation, University of Tuzla, Univerzitetska 1, 75000 \\ Tuzla, Bosnia and Herzegovina
}

Review Article

Received: $20 / 03 / 2021$

Accepted: 25/05/2021

\begin{abstract}
Perceptual-motor skills (PMS) are very important for the functioning of children in general, including children with developmental disabilities, and enable a person to, based on the stimulus through movement it acts on the space that is surrounded. This paper aims to review the research of enriched knowledge of PMS of children with disabilities, which emphasized the importance of performing activities of everyday life and the acquisition of academic skills. The papers collected a search of electronic databases using the keywords: PMS, children with disabilities, visual perception, gross and fine motor skills, visual-motor coordination, visual-motor integration. Criteria for the selection of papers have been published in full and in the last 10 years. A total of 12 works met the criteria. The results of the research review showed that children with disabilities have a limitation in PMS, and showed that PMS differ separately from the type and degree of difficulty, but differences also exist within the same category of children with disabilities. Implementation of education and rehabilitation programs improves PMS. The results showed that there is a correlation between PMS and activities of everyday life and a correlation between visual perceptions and the acquisition of reading skills. It is important to point out that PMS can be practiced and it is important to implement incentive programs for children with disabilities, but also children at risk for some difficulty, to prevent possible difficulties that children may have in performing daily life activities and in acquiring academic skills. The results of the presented research should be considered concerning the limitations of the presented research, but also to the limitations of this research.
\end{abstract}

Keywords: visual-motor integration, fine and gross motor skills, developmental difficulties

\footnotetext{
${ }^{2}$ Correspondence to:

Milena Nikolić, Faculty for Special Education and Rehabilitation, University of Tuzla

E-mail: milena.nikolic@untz.ba
} 


\section{SAŽETAK}

Perceptivno-motoričke sposobnosti (PMS) su vrlo bitne za funkcioniranje djece općenito pa tako i djece s teškoćama u razvoju, a omogućavaju osobi da na osnovu podražaja koje primi i obradi iz okoline putem pokreta djeluje u prostoru koji je okružuje. Cilj rada je da se pregledom istraživanja obogate spoznaje o PMS djece sa teškoćama u razvoju te istakne značaj istih za obavljanje aktivnosti svakodnevnog života i usvajanje akademskih vještina. Radovi su prikupleni pretragom elektroničkih baza podataka uz korištenje ključnih riječi: PMS, djeca sa teškoćama, vizuelna percepcija, gruba i fina motorika, vizuo-motorička koordinacija, vizuo-motorička integracija. Kriteriji za odabir radova bili su da su radovi objavljeni u cjelosti i u posljednjih 10 godina. Ukupno 12 radova je zadovoljilo postavljenje kriterije. Rezultati pregleda istraživanja su pokazali da djeca sa teškoćama imaju ograničenja u PMS te da se PMS razlikuju ovisno od vrste i stepena teškoće, ali razlike postoje i unutar iste kategorije djece sa teškoćama. Provođenje edukacijsko-rehabilitacijskih programa utiče na poboljšanje PMS. Rezultati su pokazali da postoji povezanost između PMS i aktivnosti svakodnevnog života, te povezanost vizuelne percepcije i usvajanja vještine čitanja. Bitno je istaknuti da se PMS mogu uvježbavati te je važno provoditi programe poticanja kod djece sa teškoćama, ali i djece sa rizikom za neku teškoću, kako bi prevenirale eventualne teškoće koje djeca mogu imati u obavljanju svakodnevnim životnim aktivnostima kao i u usvajanju akademskih vještina. Rezultate prezentiranih istraživanja treba sagledati u odnosu na ograničenja prezentiranih istraživanja, ali i u odnosu na ograničenja ovog istraživanja.

Ključne riječi: vizuo-motorna integracija, fina i gruba motorika, razvojne teškoće

\section{INTRODUCTION}

Developmental disabilities are a group of conditions caused by physical impairment, learning, language, or behavior. These conditions begin during the developmental period and can affect daily functioning and usually last throughout life (Center for Disease Control and Prevention - CDC, 2016; according to Nikolić, 2018). Children with developmental difficulties are a very heterogeneous group within which there are numerous differences concerning the type and degree of difficulties (Žic Ralić and Ljubas, 2013). According to Zrilić (2011; according to Zagorec, 2018), children with disabilities are children with reduced intellectual abilities, speech, voice, and language disorders, autism spectrum disorders, blind and visually impaired children and children with motor disorders and chronic diseases, behavioral disorders, with attention deficit disorders and children with specific learning difficulties.

When it comes to perceptual-motor development in the literature, the authors emphasize its importance for various aspects of human functioning. To better understand the significance of these abilities, it is necessary to define them. Bogović (2017) states that perception is a process in which the brain organizes data obtained through the senses and formulates them as a meaningful whole. As a complex activity of the organism, perception consists of its components of organizing, integrating, and interpreting sensory information that enable knowledge and recognition of the surrounding world. 
Motor abilities are defined as latent motor structures that are responsible for an infinite number of manifest motor reactions and can be measured and described (Findak, 2001; according to Bavčević, 2020). Kiš-Glavaš, Teodorović, and Levandovski (1997) point out that the development of motor skills assumes a certain degree of development of motor skills (e.g. walking is possible only when the ability to maintain balance is developed, or catching a ball is possible only when the ability to react is developed). Motor skills are essential for most activities in a child's life. A child who has well-developed motor skills has more success when engaging in play with peers and thus makes better use of time in kindergarten or at home (Vučinić, 2001; according to Nikodem, 2019). When it comes to motor skills in the literature, there is a division between gross and fine motor skills. Bavčević (2020) states that when large muscle groups are involved in the performance of movements, and precision is not essential, we speak of gross motor skills, while skills characterized by precise movements and the use of smaller and finer muscle structures are called fine motor skills.

Observing the above definitions, we can say that perceptual-motor abilities enable a person to act in the space that surrounds him based on the stimulus he receives and processes from the environment through movement. Levandovski, Teodorović, and Pintarić (1992) point out that perceptual-motor abilities are one of the important preconditions for successfully mastering educational content. Perception difficulties that are present in children with learning difficulties are particularly pronounced in the acquisition of teaching materials at early school age. The authors state that limitations in the process of perception can occur in one or more sensory areas, in the reception of information, their processing, and appropriate motor reactions. Igrić, Levandovski, and Kiš-Glavaš (1992) state that successful mastering of teaching contents requires, in addition to a certain level of intellectual and sensory functions, the ability to direct attention, motivation, speech potential, and a certain degree of development of perceptual-motor abilities. Nourbakhsh (2006; according to Dizdarević, 2014) states that research has confirmed a positive correlation between motor skills and academic achievement, which is why schools need to improve and influence physical activity programs to improve the perceptual-motor abilities of these children. Grubišić and Pinjatela (2019) point out that an indispensable part of the development of motor and perceptual abilities is visual perception. As part of visual-perceptual development, visual-motor integration stands out, whose role is to unite visual information from the environment with the motor performance of the hand. The brain processes visual information based on which we plan and perform coordinated motor action. The authors state that the connection of visual-motor integration with precise hand movements is a key factor in activities such as writing, drawing, and many manipulative activities. Golubović et al. (2005; according to Nikolić and Vantić-Tanjić, 2015) state that people with developmental disabilities most often show difficulties in the field of visual and auditory perception. Perceptual-motor skills improve with exercise, and the fastest progress is achieved during the early period of a child's development (Singh et al., 2010; according to Ljutić, Gros Popović, and Šikman Ljutić, 2014). The maturation of perceptual functions and perceptual-motor integration is closely related to the maturation of higher cognitive functions (Munakata, Casey \& Diamond, 2004; according to Gligorović, 2013), academic and adaptive skills (Serrien, Ivry \& Swinnen, 2007; according to Gligorović, 2013). 
Kiš-Glavaš, Teodorović, and Levandovski (1997) believe that it seems justified to start the rehabilitation of persons with greater developmental disabilities by stimulating the development of perceptual-motor abilities that would indirectly affect the development of cognitive abilities, communication, emotional and social development.

This paper aims to review the available literature and present research on perceptual-motor abilities of children with disabilities with special reference to the skills of visual perception and visual-motor integration and fine motor skills and graphomotor skills. The aim is also to enrich the knowledge about perceptual-motor abilities and emphasize their importance for the activities of everyday life and the acquisition of academic skills.

\section{METHODS OF WORK}

The search was conducted by searching electronic databases: Google Scholar, Hrčak, SCIndeks, Pub Med, ResearchGate, National Repository of Final and Graduate Papers ZIR (National and University Library in Zagreb). The following keywords were used in the search: PMS, children with disabilities, visual perception, gross and fine motor skills, visualmotor coordination, visual-motor integration. The paper analyzes 12 studies that are in line with the objectives of the paper. The selection criteria of the presented research were the time of publication (research published in the last 10 years) and the publication in full.

\section{RESULTS}

To facilitate the analysis, the research was divided into two groups: research of visual-motor integration (5 papers) and research of motor abilities ( 7 papers). Table 1. gives a summary of papers related to visual-motor integration.

Table 1. Overview of research related to visual-motor integration

\begin{tabular}{|c|c|c|c|}
\hline \multirow{2}{*}{$\begin{array}{l}\text { The authors of the } \\
\text { research, } \\
\text { year, state }\end{array}$} & \multirow[t]{2}{*}{ Research objectives } & \multicolumn{2}{|c|}{ Research methods } \\
\hline & & Measuring instruments & $\begin{array}{l}\text { Sample of } \\
\text { respondents }\end{array}$ \\
\hline $\begin{array}{l}\text { Bijonda (2017) } \\
\text { Republic of Croatia }\end{array}$ & $\begin{array}{l}\text { Identify differences } \\
\text { in the visual-motor } \\
\text { integration of } \\
\text { children with motor } \\
\text { disorders and } \\
\text { children of typical } \\
\text { development. } \\
\text { To determine the } \\
\text { effect of the } \\
\text { educational- } \\
\text { rehabilitation } \\
\text { program on visual- } \\
\text { motor integration in } \\
\text { children with motor } \\
\text { disorders of school } \\
\text { age. }\end{array}$ & $\begin{array}{l}\text { Beery-Buktenica test of } \\
\text { visual-motor integration, } \\
\text { GMFCS (Gross Motor } \\
\text { Function Classification } \\
\text { System), MACS (Manual } \\
\text { Ability Classification } \\
\text { System), and CFCS } \\
\text { (Communication Function } \\
\text { Classification System). }\end{array}$ & $\begin{array}{l}\text { The sample included } \\
8 \text { students with motor } \\
\text { disorders and } 4 \\
\text { students with typical } \\
\text { development. }\end{array}$ \\
\hline
\end{tabular}




\begin{tabular}{|c|c|c|c|}
\hline $\begin{array}{l}\text { Torres-Carrión et } \\
\text { al., (2019) } \\
\text { Spain }\end{array}$ & $\begin{array}{l}\text { In this paper, the } \\
\text { authors have focused } \\
\text { on visual-motor } \\
\text { abilities to encourage } \\
\text { better learning. The } \\
\text { proposal relies on the } \\
\text { stimulation of } \\
\text { cognitive, visual- } \\
\text { motor skills of } \\
\text { people with Down } \\
\text { syndrome (DS) using } \\
\text { exercises with a } \\
\text { gestural interaction } \\
\text { platform based on } \\
\text { the Kinect sensor } \\
\text { called TANGO H. }\end{array}$ & $\begin{array}{l}\text { Illinois test of } \\
\text { psycholinguistic abilities } \\
\text { (ITPA) and various } \\
\text { stimulation exercises } \\
\text { using TANGO: H. } \\
\text { Qualitative methods: } \\
\text { observations and } \\
\text { interviews, recordings and } \\
\text { analyzed diaries of the } \\
\text { platform as well as videos } \\
\text { of all sessions. } \\
\text { The study was conducted } \\
\text { with the approval of the } \\
\text { Down Tenerife Ethics } \\
\text { Committee. The sample } \\
\text { was selected from the } \\
\text { population of the Down } \\
\text { Tenerife Association, } \\
\text { which has } 56 \text { students } \\
\text { from the DS. Before } \\
\text { conducting research } \\
\text { written consent was taken } \\
\text { to participate in the } \\
\text { research. }\end{array}$ & $\begin{array}{l}\text { The sample }(\mathrm{N}=6 \text {, } \\
\text { two girls and four } \\
\text { boys) was divided } \\
\text { into the experimental } \\
\text { group (EG, } \mathrm{N}=3 \text {, } \\
\text { one girl and two } \\
\text { boys) and the control } \\
\text { group (CG, } \mathrm{N}=3 \text {, } \\
\text { one girl and two } \\
\text { boys). EG was } \\
\text { stimulated using } \\
\text { TANGO: } \mathrm{H} \text { with } \\
\text { gestural interaction, } \\
\text { while CG worked } \\
\text { daily in the } \\
\text { classroom without } \\
\text { the use of gestural } \\
\text { stimulation. }\end{array}$ \\
\hline $\begin{array}{l}\text { Cho, Kim, \& Yang } \\
(2015) \\
\text { Korea }\end{array}$ & $\begin{array}{l}\text { To determine the } \\
\text { effects of a visually } \\
\text { perceptive } \\
\text { intervention on } \\
\text { visual-motor } \\
\text { integration and } \\
\text { activities of daily } \\
\text { living in children } \\
\text { with cerebral palsy. }\end{array}$ & $\begin{array}{l}\text { Visual observation } \\
\text { intervention was } \\
\text { conducted for } 8 \text { weeks, } 3 \\
\text { times a week for } 30 \\
\text { minutes per session, for a } \\
\text { total of } 24 \text { sessions. All } \\
\text { children were assessed } \\
\text { using VMI and WeeFIM } \\
\text { to assess visual and motor } \\
\text { integration and daily life } \\
\text { activity, immediately } \\
\text { before and after } 8 \text { weeks } \\
\text { of intervention. }\end{array}$ & $\begin{array}{l}\text { The study included } \\
56 \text { children with } \\
\text { cerebral palsy. }\end{array}$ \\
\hline $\begin{array}{l}\text { Elbasan, Atasavun, } \\
\text { \& Düger (2011) } \\
\text { Turkey }\end{array}$ & $\begin{array}{l}\text { To examine the } \\
\text { effect of visual } \\
\text { perception and motor } \\
\text { functioning in daily } \\
\text { activities of children } \\
\text { with disabilities. }\end{array}$ & $\begin{array}{l}\text { The Functional } \\
\text { Independence Scale was } \\
\text { used to assess daily life } \\
\text { activities } \\
\text { (WeeFIM); Visual } \\
\text { perception was assessed } \\
\text { using visual perception } \\
\text { tests (MVPT3); GMFM } \\
\text { was used to assess motor } \\
\text { function. }\end{array}$ & $\begin{array}{l}\text { The study included } \\
35 \text { children with mild } \\
\text { intellectual } \\
\text { disabilities. }\end{array}$ \\
\hline $\begin{array}{l}\text { Baluoti, Bayat, \& } \\
\text { Alimoradi (2012) } \\
\text { Iran }\end{array}$ & $\begin{array}{l}\text { Establishing a link } \\
\text { between visual } \\
\text { perception and }\end{array}$ & $\begin{array}{l}\text { Marriane Frostig } \\
\text { developmental test of } \\
\text { visual perception and }\end{array}$ & $\begin{array}{l}\text { The sample included } \\
50 \text { students ( } 30 \text { boys } \\
\text { and } 20 \text { girls) who }\end{array}$ \\
\hline
\end{tabular}




$\begin{array}{lll}\begin{array}{l}\text { reading difficulties of } \\ \text { students attending } \\ \text { the Learning }\end{array} & \begin{array}{l}\text { standardized collection of } \\ \text { Fallah Chai tests. }\end{array} & \begin{array}{l}\text { attended these } \\ \text { centers. }\end{array} \\ \begin{array}{l}\text { Disability Center and } \\ \text { the Counseling and }\end{array} & \\ \text { Psychological } & \\ \text { Service Center of the } & \\ \text { educational } \\ \text { organization in the } \\ \text { city of Ahwaz. }\end{array}$

The results of a study conducted by Bijonda (2017) show that there is a statistically significant difference between the experimental group of students with motor disorders and the control group of students without difficulties in the initial results on the variables visualmotor integration and visual perception, where students without disabilities had significantly better results. After the initial assessment, students with motor disorders were included in the educational-rehabilitation program to encourage visual-motor integration. The program was implemented as part of an extended professional procedure two times a week for 45-60 minutes and spent a total of 3 months. At the final assessment, after the implementation of the educational-rehabilitation program for students with motor disorders, students without difficulties had statistically significantly better results on the variables of visual-motor integration and motor coordination. On the variable visual perception, in the final assessment, students from the experimental group had better results than students without difficulties, but this difference was not statistically significant.

Cho, Kim, \& Yang (2015) in their study examined the impact of visual-perceptual training on visual-motor integration and daily life activities in children with cerebral palsy. Visualperceptual training was conducted for a total of 8 weeks, 3 times a week for 30 minutes per session, a total of 24 sessions. The results showed improvement and a positive effect of training on visual-motor integration and daily life activities for all 56 children with cerebral palsy who participated in the study, and the improvements were statistically significant.

Elbasan, Atasavun, \& Düger (2011) examined the effect of visual perception and motor functioning in activities of daily living in children with mild intellectual disabilities, and the results showed that there is a positive correlation between GMFM results and the overall score of the Functional Independence Scale, including self-help, mobility, and locomotion. Visual memory and visual closure and overall visual perception test scores were significantly related to the overall score of the Functional Independence Scale, while visual discrimination was significantly related to self-care on the Functional Independence Rating Scale.

In addition to the influence of visual perception on the performance of everyday life activities, it is also important in the acquisition of academic skills. Baluoti, Bayat, \& Alimoradi (2012) examined the relationship between visual perception and reading, and the results showed that there is a significant negative relationship between visual perception and reading difficulties of students with dyslexia, if visual perception skills decrease reading difficulties in children increase. 
Torres-Carrión et al., (2019) focused on encouraging visual-motor integration skills in people with Down syndrome. To stimulate learning, visual cognitive stimulations were used in the experimental group, and the results of the study did not show statistically significant differences between these two groups, while the results of qualitative methods showed an improvement in visual-motor cognitive skills.

An overview of the papers included in the review related to motor skills (fine motor skills and graphomotor skills) is given in Table 2 .

Table 2. Overview of research related to motor skills (fine motor skills and graphomotor skills)

\begin{tabular}{|c|c|c|c|}
\hline \multirow{2}{*}{$\begin{array}{l}\text { The authors of the } \\
\text { research, } \\
\text { year, state }\end{array}$} & \multirow[b]{2}{*}{ Research objectives } & \multicolumn{2}{|c|}{ Research methods } \\
\hline & & Measuring instruments & Sample of respondents \\
\hline $\begin{array}{l}\text { Nobusako et al., (2018) } \\
\text { Japan }\end{array}$ & $\begin{array}{l}\text { Investigate the factors } \\
\text { that affect poor manual } \\
\text { dexterity, provide useful } \\
\text { behavioral markers for } \\
\text { understanding the neural } \\
\text { mechanism of } \\
\text { developmental } \\
\text { coordination disorder } \\
\text { and promote the } \\
\text { development of new } \\
\text { neurorehabilitation } \\
\text { techniques to improve } \\
\text { poorer manual dexterity. }\end{array}$ & $\begin{array}{l}\text { Manual Dexterity Test - } \\
\text { Battery for Assessing } \\
\text { Movement for Children } \\
\text { (Second Edition), } \\
\text { Experimental Tasks } 1 \\
\text { and 2, and the } \\
\text { Depression Self- } \\
\text { Assessment Scale for } \\
\text { Children (DSRS-C). }\end{array}$ & $\begin{array}{l}\text { The sample was divided } \\
\text { into two subsamples: } \\
\text { children who were } \\
\text { thought to have a } \\
\text { developmental } \\
\text { coordination disorder } \\
\text { and children of typical } \\
\text { development. The first } \\
\text { group consisted of } 29 \\
\text { children with poorer } \\
\text { manual dexterity, while } \\
\text { the second group } \\
\text { consisted of } 42 \text { children } \\
\text { with normal manual } \\
\text { dexterity. }\end{array}$ \\
\hline $\begin{array}{l}\text { Miller, Chukoskie, Zinni, } \\
\text { Townsend, \& Traune } \\
\text { (2014) } \\
\text { San Diego, California }\end{array}$ & $\begin{array}{l}\text { To examine the } \\
\text { relationship of specific } \\
\text { basic motor function, } \\
\text { including eye movement, } \\
\text { with ideational dyspraxia } \\
\text { (sequences of skillful } \\
\text { movements), as well as } \\
\text { the possible role of } \\
\text { visual-motor integration } \\
\text { in dyspraxia. }\end{array}$ & $\begin{array}{l}\text { Praxis and Basic Motor } \\
\text { Tests. } \\
\text { Visual-motor integration } \\
\text { assessment test (Beery } \\
\text { VMI) } \\
\text { Gap / Null / Overlap } \\
\text { Paradigm. }\end{array}$ & $\begin{array}{l}\text { The sample included } 20 \\
\text { children with autism } \\
\text { spectrum disorders aged } \\
8-15 \text { years ( } 17 \text { boys and } \\
3 \text { girls) and } 20 \text { children } \\
\text { of typical development } \\
\text { ( } 16 \text { boys and } 4 \text { girls). }\end{array}$ \\
\hline $\begin{array}{l}\text { Park (2015) } \\
\text { Korea }\end{array}$ & $\begin{array}{l}\text { Comparison of } \\
\text { differences in motor and } \\
\text { processing skills in } \\
\text { children with } \\
\text { developmental } \\
\text { disabilities. }\end{array}$ & $\begin{array}{l}\text { Motor and process skills } \\
\text { assessment test, AMPS. }\end{array}$ & $\begin{array}{l}\text { The sample included } 39 \\
\text { children with disabilities } \\
\text { who attended the N } \\
\text { hospital in South Korea, } \\
25 \text { boys }(64.1 \%) \text { and } 14 \\
\text { girls }(35.9 \%) \text {, with an } \\
\text { average age of } 7.5 \text { years } \\
(\mathrm{SD}=2.6) \text {. } \\
\text { This study was approved } \\
\text { by the institutional } \\
\text { review board of Korea } \\
\text { University (KU-IRB-11- } \\
\text { 09-P-1). }\end{array}$ \\
\hline
\end{tabular}




\begin{tabular}{ll}
\hline Skowroński, Winnicki, & Analyze the relationship \\
Bednarczuk, Rutkowska & between physical fitness, \\
\& Rekowski (2018) & gross and fine motor \\
Poland & skills, and levels of \\
& functioning in \\
& schoolchildren with \\
& intellectual disabilities \\
& (IT).
\end{tabular}
(IT).

Motor difficulties, as
well as gross and fine
motor skills, were
measured by BOT-2,
TGMD-2, and Eurofit
Special tests. The level
of functioning in society
was assessed by a
specially designed
questionnaire based on
the ICF.

\begin{tabular}{ll}
\hline Marić (2017) & $\begin{array}{l}\text { Determine if there is a } \\
\text { Republic of Croatia }\end{array}$ \\
& $\begin{array}{l}\text { degree of development } \\
\text { of stereopsis and } \\
\text { dexterity in fine and } \\
\text { gross motor skills of } \\
\text { children with intellectual } \\
\text { disabilities. }\end{array}$ \\
& To examine the impact \\
& of an individual \\
& educational- \\
Sehabilitation program on \\
Republic of Croatia & the development of \\
& motor and perceptual- \\
& cognitive activity in a \\
child with cerebral palsy.
\end{tabular}

Stereo test (random point sharpness test 2 with Lea Symbols $\left.{ }^{\circledR}\right)$.

Likert scale for assessing fine and gross motor skills. variables from the Guide for assessment and creation of individual development programs
The study involved 62 respondents aged 9 to 24 years. Due to the size and homogeneity of the group, the results of 26 respondents were taken into account in the analysis: 12 girls and 14 boys with moderate IT.
The sample included 27 children with IT without motor problems. The mean age of the examined children was 11 years.

$\begin{array}{ll}\text { For this research, a } & \text { The study involved a boy } \\ \text { measuring instrument } & \text { with cerebral palsy, a } \\ \text { was created based on the } & \text { bilateral spastic type at } \\ \text { existing standardized } & \text { the age of 6 years. }\end{array}$
for children from third to sixth year (Pištoljević and Majušević, 2015), ACADIA test of developmental abilities, and Frostig developmental test of visual perception. The assessment also used tasks from the test for the assessment of manipulative dexterity of the hands (LaFaye), the test of differentiation of finger motility (Rey), and the questionnaire for the assessment of knowledge of body parts (Stevanović, Bojanin, 1979).

\begin{tabular}{ll}
\hline Matijević-Mikelić, & The aim was to \\
Košiček, Crnković, & determine the frequency \\
Trifunović-Maček i & $\begin{array}{l}\text { of graphomotor } \\
\text { difficulties in children }\end{array}$ \\
Grazio (2011) & $\begin{array}{l}\text { with perinatal damage to } \\
\text { the central nervous } \\
\text { Republic of Croatia }\end{array}$ \\
& $\begin{array}{l}\text { system and premature } \\
\text { babies. }\end{array}$
\end{tabular}

$\begin{array}{ll}\begin{array}{l}\text { Retrospective research } \\ \text { by reviewing the archive }\end{array} & \begin{array}{l}\text { The study included } 50 \\ \text { children aged } 12 \text { to } 36\end{array} \\ \begin{array}{l}\text { in the period from April } \\ \text { to September } 2010 \text { for }\end{array} & \\ \text { children up to } 3 \text { years of } & \\ \text { age who were } \\ \text { hospitalized at the Clinic } \\ \text { for Rheumatology, } \\ \text { Physical Medicine and }\end{array}$




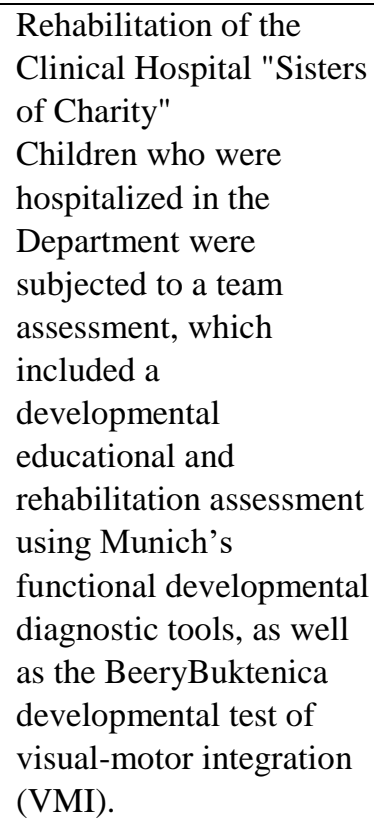

Nobusako et al., (2018) concluded in their study that children who were thought to have a developmental coordination disorder have deficits in visual-motor temporal integration and the function of automatic imitation compared to children of typical development. This study investigated whether these two groups of children differ when it comes to the characteristics of autism spectrum disorders (ASD), attention deficit and hyperactivity disorder (ADHD) characteristics, and depressive symptoms, because these characteristics often occur associated with developmental coordination disorders. Through the introductory part of the study, the authors explain that developmental coordination disorder is often diagnosed as ADHD and that children with developmental coordination disorder often develop symptoms of depression. Multiple regression analysis revealed that the delay-detection threshold, which indicated visuomotor temporal integration, was the greatest predictor of poor manual dexterity. The results showed that children who were thought to have a developmental coordination disorder had more symptoms of depression compared to children of typical development. The results of the SCQ test (battery for assessing the social cognitive functions associated with ASD) were significantly higher in the group of children considered to have developmental coordination disorder than the group of children of typical development. These results show that children considered to have developmental coordination disorders have the characteristics of autism spectrum disorders and that the severity of ASD traits is associated with a deterioration in manual dexterity. Also, the results showed that there is a significant association between ADHD traits and poorer manual dexterity in children with suspected developmental coordination disorder compared to children of typical development. The results of a study conducted by Miller, Chukoskie, Zinni, Townsend \& Traune (2014) showed that children with autism compared to the control group of children of typical development show a significantly higher level of dyspraxia, have a poor effect on tasks assessing basic motor function, overall worse eye movement performance (saccades or rapid simultaneous movements of both eyes started more slowly in children with autism and it took more saccades to achieve the goal than in children of typical development). Standard results from the Beery VMI showed poorer performance in children with autism compared to typical children in the visual-motor integration test and the supplementary motor coordination test. 
However, on the supplementary visual perception test, there were no significant differences between the groups. As there are significant group differences in the dependent measures, correlations were calculated within the group. Neither in children with autism nor children of typical development was there an association between ideational dyspraxia and a simple motor control index. However, in children with autism, higher ideational dyspraxia was significantly associated with poorer performance on standardized tests of visual-motor integration and motor coordination. These measures were not associated with children with typical development. Also, in children with autism, greater ideational dyspraxia was associated with more pronounced traits of autism and with increased repetition of behaviors and limited interests.

Park (2015) compared the motor and processing skills of participants between three different disabilities: pervasive developmental disorder, cerebral palsy, and intellectual disabilities. Data were analyzed using descriptive statistics and one-way ANOVA. The results showed that there are significant differences in motor skills between diagnoses. The group in which the subjects had cerebral palsy showed poorer motor skills than pervasive developmental disorder and intellectual disabilities.

When it comes to the gender of children with intellectual disabilities and motor skills, the results of a study conducted by Skowroński, Winnicki, Bednarczuk, Rutkowska, \& Rekowski (2018) showed that girls have better motor skills than boys, ie they showed a higher level of functioning. The boys, despite better physical fitness, were classified at a lower level of functioning.

Maric (2017) in her study found that there is a statistically significant association between the degree of development of stereopsis (the highest level of binocular vision) and dexterity in fine and gross motor skills in children with intellectual disabilities.

When it comes to graphomotor abilities Matijević-Mikelić, Košiček, Crnković, TrifunovićMaček, and Grazio (2011) examined the frequency of difficulties in graphomotor abilities in neurorisk children, and the results showed that in the examined children in $72 \%$ of cases the drawing was within expected for age, in 13 children the graphic abilities were below those expected for age, while one child did not show functional pen use. The results of this study suggest that despite good initial compensation in the early development of graphomotor skills, it is necessary to monitor this population of children to prevent possible later difficulties in the development of graphomotor skills and writing.

The impact of educational-rehabilitation programs for the improvement of motor and perceptual-cognitive abilities in a child with cerebral palsy was investigated by Šišerko (2017) in her case study, and the results showed that in no area of assessment - gross motor skills, fine motor skills, graphomotor skills, and perceptual-cognitive area) not all variables resulted in improvement. However, the results point to progress in most of the variables from each of the mentioned areas. The biggest shift is visible in the field of graphomotor skills. The child never held a pen in his hand before beginning the program. Consequently, his graphomotor skills were very poor or rather did not exist at all, while the final assessment indicates great progress in the field of graphomotor skills. The child's drawing of a man on the final measurement contains more than five elements and successfully redraws the basic shapes and lines. The grip is correct most of the time during the final assessment, only the elbow is still raised off the ground. Great progress can be seen in some tasks in the field of fine motor skills and visual perception. 
The author points out that the educational-rehabilitation program was conducted once or twice a week, in the period from October 2017 to June 2018. During that time, the therapy was not conducted for two months due to the unplanned absence of the child. Nevertheless, a total of 30 hours of therapy was performed. Each therapy lasted 60 minutes, with several shorter breaks. As children with developmental disabilities differ from each other in the type and degree of impairment, so they also differ in perceptual-motor abilities, they differ from each other, but also in comparison with children of typical development. The results of the study (Miller, Chukoskie, Zinni, Townsend \& Traune, 2014) show that children with autism compared to children of typical development show a significantly higher level of dyspraxia, have a poor effect on tasks assessing basic motor function, and poorer performance on the test of visual-motor integration and a supplementary motor coordination test. The authors point out that although the sample size was small to examine the association between the measures, strong correlations were observed in the group of children with autism in the measures of visual-motor integration and motor coordination with practice.

\section{DISCUSSION}

Analyzed research shows that children with developmental disabilities differ in PMS concerning peers of typical development (Bijonda, 2017), as well as to the type and degree of developmental difficulties (Park, 2015). Given the differences between children and the fact that two children with the same diagnosis do not have the same level of functioning and the same success in certain skills, this indicates the need for each child to be seen as an individual and that each child should create an incentive program based on his abilities. There is no program to encourage perceptual-motor abilities that are constructed based on the child's age, gender, or diagnosis. Research indicates differences among children with different diagnoses, and children with cerebral palsy show poorer motor skills than children with pervasive developmental disorder and children with intellectual disabilities (Park, 2015). It is important to emphasize that children differ not only when it comes to diagnoses but also within the same category of children, that is children with the same diagnosis have differences. The results of the research show that girls with intellectual disabilities have better motor skills than boys with intellectual disabilities (Skowroński, Winnicki, Bednarczuk, Rutkowska \& Rekowski, 2018), but also that there is a connection between stereopsis (highest level of binocular vision) and dexterity in fine and gross motor skills in children with intellectual disabilities (Marić, 2017). Given that research shows differences between children with cerebral palsy and children with pervasive developmental disorders and intellectual disabilities, the question arises: Is there a difference in perceptual-motor abilities between children who have difficulties that are not based on motor disorders (children with disabilities, children with autistic spectrum disorders, children with hearing impairment, visual impairment), and whether and to what extent the distinguish children with difficulties in perceptual-motor abilities concerning involvement in early treatment and encouragement of these abilities? 
The results of studies presented in the paper aimed at examining the impact of the educational-rehabilitation program on perceptual-motor abilities (Bijonda, 2017; Šešerko, 2019) showed progress in some of the perceptual-motor abilities, although in some areas the progress was not statistically significant, but existed, which suggests that educationalrehabilitation treatment can improve perceptual-motor skills in children with developmental disabilities. Incentive programs conducted within these studies lasted 3 months: treatment twice a week for 45-60 minutes, a total of 24 treatments (Bijonda, 2017), and 6 months: once to twice a week, a total of 30 treatments each treatment 60 minutes (Šešerko, 2019). Observing the above, we see that programs to encourage perceptual-motor abilities for 30 treatments can improve perceptual-motor abilities in children with disabilities. This leads us to analyze the importance of long-term implementation of educational-rehabilitation programs to stimulate perceptual-motor abilities and measure progress. To encourage learning in people with Down syndrome, Torres-Carrión et al., (2019) used visual-cognitive stimulation in their study, although no statistically significant differences were found. The results of qualitative methods showed that there is still progress in perceptual-motor cognitive abilities. The authors cite the study's limitations as being limited to objective assessment from ITPA test subtests that include visual-motor cognitive abilities before and after stimulation through the TANGO: $\mathrm{H}$ gestural interaction platform and exercises specifically prepared for this study. They point out that the study sample was limited to six individuals $(\mathrm{CG}=3, \mathrm{EG}=$ 3). The authors state that the aim of this study is not to extend these results to the entire population of people with Down syndrome but to contribute to improving the quality of life of people with Down syndrome by scientifically evaluating the technological platform for gestural stimulation.

Given that perceptual-motor abilities affect everyday life activities, research shows that the implementation of visual-perceptual training programs has a positive effect on visual-motor integration and daily life activities and leads to improved functions in children with cerebral palsy (Cho, Kim, \& Yang 2015), and subparameters of visual perception are an important factor for independence in the activities of everyday life of children with mild intellectual disabilities (Elbasan, Atasavun, \& Düger, 2011). As limitations in their study Elbasan, Atasavun \& Düger (2011) point out the absence of a control group consisting of healthy children for comparison. The authors state that they did not investigate the connection between mental status and activities of everyday life. Given the above, the possibility of further studies and analyzes opens, that is to analyze the impact of stimulation of perceptualmotor abilities in people with varying degrees of intellectual disabilities on functioning in the activities of everyday life?

Perceptual-motor abilities are also important for learning and acquiring academic skills (reading and writing). Research shows that there is an association between visual perception and reading difficulties in children with dyslexia, and the worse the visual perception, the greater the reading difficulties (Baluoti, Bayat, \& Alimoradi 2012). This indicates the importance of encouraging perceptual-motor skills in the preschool period so that the child is ready to go to school and acquire academic skills.

Tükel (2013 to Bijonda, 2017) points out that in children with neurodevelopmental disabilities, because of the difficulty of visual-motor integration, development, and acquisition of graphomotor skills is much more difficult. 
According to the same author, no matter what kind of neurological damage, the problem is most often seen in graphomotor abilities. Neurological symptoms that affect visual-motor integration can be in motor control, visual system, and mechanisms of attention and memory. In developmental disorders, difficulties in visual-motor integration occur mostly in preschool or school age and are reflected as difficulties in drawing and/or writing that can monitor motor difficulties and learning disabilities. Nobusako et al., (2018) believe that developmental coordination disorder has a neurological basis, and it represents deficits in the internal model and the mirror-neuron system (MNS) in the parietal lobe and cerebellum. The results of a study conducted by these authors show that developmental coordination disorder is the biggest predictor of poor manual dexterity, but point out that the limitations of this study were children included in the sample, that is children considered to have developmental coordination disorder did not fully meet diagnostic criteria A DSM-5 manuals. Therefore, current results are limited to the results of children with disabilities in manual dexterity. The authors state that further research is needed on a sample of participants who fully meet diagnostic criteria A through D of the DSM-5 for developmental coordination disorder.

When it comes to children with neurodevelopmental risk, research shows that this population of children should be monitored, and the rapid detection of difficulties in the development of graphomotor skills and the use of appropriate therapeutic procedures can prevent the development of greater difficulties in writing later (Matijevic-Mikelic, Kosicek, Crnkovic, Trifunovic-Macek and Grazio 2011). Skowroński, Winnicki, Bednarczuk, Rutkowska, \& Rekowski (2018) point out that the literature indicates frequent learning difficulties, attention, and fine motor skills in preschool and especially in school-age in children born with neurodevelopmental risk.

Since fine motor skills are a prerequisite for performing daily life activities (dressing, feeding, combing, etc.), limitations in fine motor activities will lead to limitations in these activities. Since the perceptual-motor skills are also the very important question arises whether the parents and educators of children with disabilities aware of the importance of perceptual-motor skills at an early age?

Limitations in this research were: a small number of available research following the objectives of the work, insufficient number of research conducted in our country, inability to access certain electronic databases and/or papers, inability to access complete papers (availability of abstracts only), time frame of the research taken in review and analysis of research covering all types of developmental difficulties. Due to these limitations, the results of the research should be accepted with reservations, and therefore there is a need for further analysis of the research perceptual-motor abilities of children with disabilities. In future review papers, it would be good to focus on the analysis of research concerning a particular type of developmental difficulty. 


\section{CONCLUSION}

Based on the review of research about perceptual-motor abilities in children with developmental disabilities, can be concluded the next:

- Perceptual-motor abilities of children with developmental disabilities differ in comparison with children of typical development, as well as concerning the type and degree of developmental difficulties;

- Children with cerebral palsy show poorer motor skills than children with a pervasive developmental disorder and intellectual disabilities;

- Differences in perceptual-motor abilities exist within the same category of children, so girls with intellectual disabilities have better motor skills than boys;

- Educational-rehabilitation treatment can improve the perceptual-motor abilities of children with developmental disabilities;

- When it comes to children with intellectual disabilities, it has been shown that there is a correlation between stereopsis (the highest level of binocular vision) and dexterity in fine and gross motor skills, that visual perception is an important factor for independence in everyday life of children with mild intellectual disabilities;

- Visual-cognitive stimulation may affect progress in the perceptual-motor cognitive abilities of children with Down syndrome;

- Implementation of visual-perceptual training programs improves visual-motor integration and activities of everyday life of children with cerebral palsy;

- There is a correlation between visual perception and reading difficulties in children with dyslexia, the worse the visual perception, the greater the reading difficulties;

- Children with neurodevelopmental risk have more frequent difficulties in graphomotor abilities, learning difficulties, attention, and fine motor skills.

Children with developmental difficulties have difficulties in perceptual-motor abilities, most difficulties in visual-motor integration, fine motor skills, and manual dexterity, and graphomotor abilities. Limitations in perceptual-motor abilities lead to limitations in everyday life activities and the acquisition of academic skills. Also, children with disabilities differ from each other when it comes to perceptual-motor abilities and children with motor disorders have greater limitations in perceptual-motor abilities than children with disabilities whose basis is not a motor disorder, but also within the same category of children, there are differences in perceptual-motor abilities. Given that perceptual-motor abilities improve if educational-rehabilitation programs are implemented to encourage these abilities, it is necessary to include children with disabilities in the system of early intervention and rehabilitation through which work will be done to encourage these abilities in children with disabilities and encourage the overall development of children, exploiting their potential and improving the functioning of the child in everyday life activities. The presented conclusions should be considered concerning the limitations of the research, and the need for further analysis of research on perceptual-motor abilities to only one type of difficulty is indicated. Research on children's perceptual-motor abilities needs to continue to be conducted concerning the research questions that have opened up through the discussion in this paper. 


\section{REFERENCES}

1. Baluoti, A., Bayat, M., \& Alimoradi, M. (2012). Relationship between visual perception and reading disability in primary students (first, second, third, grade) of Ahwaz city. International Research Journal of Applied and Basic Sciences 3 (10), 2091-2096.

2. Bavčević, D. (2020). Vizualno-motorička integracija, analiza razvojnih trendova kod djece $i$ učenika u predškoli $i$ primarnoj edukaciji [Doktorska disertacija]. Preuzeto 14.01.2021. s https://urn.nsk.hr/urn:nbn:hr:221:276574.

3. Bijonda, L. (2017). Poticanje vizualno - motoričke integracije kod učenika s motoričkim poremećajima u osnovnoj školi [Diplomski rad]. Preuzeto 03.11.2020. s https://urn.nsk.hr/urn:nbn:hr:158:203680.

4. Bogović, I. (2017). Razvoj percepcije [Diplomski rad]. Preuzeto 13.01.2021. s https://urn.nsk.hr/urn:nbn:hr:134:213106.

5. Cho, M., Kim, D., \& Yang, Y. (2015). Effects of visual perceptual intervention on visualmotor integration and activities of daily living performance of children with cerebral palsy. Journal of Physical Therapy Science 27 (2), 411-413. doi: 10.1589/jpts.27.411.

6. Dizdarević, A. (2014). Specijalna edukacija i rehabilitacija djece sa intelektualnim $i$ razvojnim teškoćama - teorija, praksa i istraživanje. Tuzla: Printcom d.o.o.

7. Elbasan, B., Atasavun, D., \& Düger, T. (2011). Effects of visual perception and motor function on the activities of daily living in children with disabilities. Fizyoter Rehabilitasyon 22 (3), 224-230.

8. Gligorović, M. (2013). Klinička procena i tretman teškoća u mentalnom razvoju. Beograd: Univerzitet u Beogradu Fakultet za specijalnu edukaciju i rehabilitaciju Izdavački centar- CIDD.

9. Grubišić, I., i Pinjatela, R. (2019). Utjecaj programa poticanja psihomotoričkog razvoja na vizualno-motoričku integraciju, motoričke sposobnosti i crtež čovjeka u predškolske djece. Školski vjesnik 68 (2), 508-517.

10. Igrić, L., Levandovski, D., i Kiš-Glavaš, L. (1992). Perceptivne sposobnosti djece bez teškoća u razvoju i djece usporena kognitivnog razvoja (PMZ-test). Defektologija 28 (12), 21-36.

11. Kiš-Glavaš, L., Teodorović, B., i Levandovski, D. (1997). Program bazične perceptivnomotoričke stimulacije. Zagreb: Fakultet za defektologiju Sveučilišta u Zagrebu.

12. Levandovski, D., Teodorović, B., i Pintarić, L. (1992). Spremnost za učenje djece s lakom mentalnom retardacijom. Defektologija 28 (1-2 suplement 2), 9-29.

13. Ljutić, T., Gros Popović, D., i Šikman Ljutić, Z. (2014). Selektivne perceptivnomotoričke, glazbenoritmičke stimulacije i grafomotorna aktivnost djeteta s cerebralnom paralizom. Hrvatska revija za rehabilitacijska istraživanja, 50 (2), 30-42.

14. Marić, A. (2017). Povezanost stereovida i grube te fine motorike djece s intelektualnim teškoćama [Diplomski rad]. Preuzeto 16.01.2021. s https://urn.nsk.hr/urn:nbn:hr:158: 081374.

15. Matijević-Mikelić, V., Košiček, T., Crnković, M., Trifunović-Maček, Z., i Grazio, S. (2011). Razvoj ranih grafomotoričkih sposobnosti u djece s neurorazvojnim rizikom. Acta clinica Croatica 50 (3), 317-321.

16. Miller, M., Chukoskie, L., Zinni, M., Townsend, J., \& Traune, D. (2014). Dyspraxia, motor function and visual-motor integration in autism. Behavioural Brain Research 269 (1), 95-102. 
17. Nikodem, M. (2019). Poticanje motoričkih sposobnosti i samoregulacije kod djeteta $s$ razvojnim odstupanjima [Diplomski rad]. Preuzeto 18.01.2021. s https://urn.nsk.hr/urn:nbn:hr:158:859642.

18. Nikolić, M. (2018). Uvod u edukacijsko-rehabilitacijsku znanost. Tuzla: In Scan d.o.o. Tuzla.

19. Nikolić, M., i Vantić-Tanjić, M. (2015). Uvod u intelektualne teškoće. Tuzla: OFF-SET.

20. Nobusako, S., Sakai, A., Tsujimoto, T., Shuto, T., Nishi, Y., Asano, D., et al. (2018). Deficits in visuo-motor temporal integration impacts manual dexterity in probable developmental coordination disorder. Frontieres in Neurology 9 (114), doi: 10.3389/fneur.2018.00114.

21. Park, MO. (2015). Comparison of motor and process skills among children with different developmental disabilities. Journal of Physical Therapy Science 27 (10), 3183-3184, doi: 10.1589/jpts.27.3183.

22. Skowroński, W., Winnicki, W., Bednarczuk, G., Rutkowska, I., \& Rekowski, W. (2018). Analysis of Correlations Between Gross and Fine Motor Skills, Physical Fitness, and the Level of Functioning in Schoolchildren with Intellectual Disabilities. Polish Journal of Sport and Tourism 25, 16-22, doi: https://doi.org/10.2478/pjst-2018-0003.

23. Šešerko, S. (2019). Utjecaj edukacijsko-rehabilitacijskog programa na perceptivnokognitivni i motorički razvoj djeteta s cerebralnom paralizom [Diplomski rad]. Preuzeto 17.01.2021. s https://urn.nsk.hr/urn:nbn:hr:158:207772.

24. Torres-Carrión, P. V., González-González, C. S., Toledo-Delgado, P., Muñoz-Cruz, V., Gil-Iranzo, R., Reyes-Alonso, N., et al. (2019). Improving cognitive visual-motor abilities in individuals with down syndrome. Sensors (Basel) 19(18), doi: 10.3390/s19183984.

25. Zagorec, A. (2018). Kompetencije učitelja za rad s djecom s teškoćama u razvoju [Diplomski rad]. Preuzeto 18.01.2021. s https://urn.nsk.hr/urn:nbn:hr:147:502361.

26. Žic Ralić, A., i Ljubas, M. (2013). Prihvaćenost i prijateljstvo djece i mladih s teškoćama u razvoju. Društvena istraživanja: časopis za opća društvena pitanja 22 (3), 435-453. 